\title{
The taxonomic significance of seed morphology in the Passiflora subgenus Astrophea [Passifloraceae]
}

\section{Ana Carolina Mezzonato-Pires ${ }^{\star *}$, Cláudia Barbieri Ferreira Mendonça', Michaele Alvim Milward-De-Azevedo² and Vania Gonçalves-Esteves ${ }^{1}$}

Received: November 25, 2016

Accepted: January 23, 2017

\begin{abstract}
The center of diversity for Passiflora subg. Astrophea is in low altitude areas of northern South America. The majority of species of this group are difficult to find in nature. Seed morphology was described in detail for 25 species of Passiflora subgenus Astrophea, a subgenus that until now did not exist. For morphological analysis, 20 seeds per species were measured for length, width and thickness, and the arithmetic means calculated. The seeds varied in length, width and thickness. Eight types of ornamentation were found. The margins varied among crestate, dentate, parted, entire and parted-crestate. The seed apex can be distinguished by the shape and position of the apical appendage. Seed shape varied among obovate, lanceolate, cordiform, and oblong to elliptical. An identification key was developed and a PCA was performed both using the principal morphological characters. Morphological characters of seeds are a new source of data for delimiting taxa with quite conflicting morphological boundaries, such as seen here with the Passiflora subgenus Astrophea. Furthermore, seed morphology is especially useful for the identification of specimens with only fruits and, consequently, seeds available.
\end{abstract}

Keywords: Astrophea, fruits, morphological characters, seeds, systematics

\section{Introduction}

Passiflora subgenus Astrophea is one of five subgenera belonging to the genus Passiflora. It is comprised of about 60 species distributed in South and Central America, with only two species in the latter, Passiflora pittieri and Passiflora tica (Escobar 1994). The major center of diversity for Passiflora subg. Astrophea is in areas of low altitude in northern South America (Ulmer \& MacDougal 2004). In Brazil, the subgenus is represented by approximately 25 species (BFG 2015) with the greatest concentration being in the north. According to Ulmer \& MacDougal (2004), species of Passiflora subg. Astrophea are similar to typical Passiflora but with unique morphological characteristics, and so are considered the most unusual of the genus. In addition to having a climbing habit, this subgenus also exhibits shrub or tree habits, and has tiny stipules, entire leaf blades, two glands on the petiole, tiny bracts, and campanulate lily flowers with a yellow corona or red tubular flowers with a reddish corona. The majority of species of this group are rare and difficult to find in nature. Species identification of specimens in the absence of flowers is usually impossible since most of the diagnostic characters are in the flowers, and so when specimens are only fruits, seeds can serve as a valuable identification tool.

The importance of describing seeds extends beyond taxonomy and systematics to archaeology, paleobotany and even to farming and gardening by helping identify

\footnotetext{
${ }^{1}$ Departamento de Botânica, Museu Nacional, Universidade Federal do Rio de Janeiro, Quinta da Boa Vista, São Cristovão, 20940-040, Rio de Janeiro, RJ, Brazil

${ }^{2}$ Departamento de Ciências do Meio Ambiente, Instituto Três Rios, Universidade Federal Rural do Rio de Janeiro, Av. Prefeito Alberto da Silva Lavinas 1847, 25802-100, Três Rios, RJ, Brazil
}

*Corresponding author: carolina.mezzonato@gmail.com 
cultured species (Johri 1984). According to Haridasan \& Mukherjee (1988), environmental conditions have little influence on the characteristics of the seed surface, and thus these characters should better reflect the underlying genetics and be more useful in analyses of phylogenetic relationships. In a morphological study of the seeds of 51 species of the genus Passiflora, Pérez-Cortéz et al. (2002) demonstrated the existence of great diversity. Ulmer \& MacDougal (2004) claim that the size and, especially, the surface of seeds are often useful characters for taxonomy.

As an understudied subgenus with poorly known and defined species, pollen studies of Passiflora subg. Astrophea were conducted with the hope of finding characters useful in species delimitations. The species of Passiflora subg. Astrophea analyzed (Mezzonato-Pires et al. 2015) revealed various important characters.

Thus, the present study aims to describe the seed morphology of 25 species of the Passiflora subg. Astrophea in order to identify characters with taxonomic potential that can assist in classification and be used in future phylogenetic analyses.

\section{Materials and methods}

The seeds of 25 species of the Passiflora subgenus Astrophea (DC.) Mast. were studied (S1 in supplementary material). The material used was taken from exsicates deposited in herbaria whose acronyms are in accordance with the Index Herbariorum (Thiers, continuously updated): IAN, INPA, MG, MO, NYBG, R, RB and UB.

For morphological analysis, 20 seeds per species (when possible) were measured for length, width and thickness (Fig. 1 ), and the arithmetic means calculated. Description of the base, apex, margin and ornamentation used the terminology of Perez-Cortez et al. (2002) with some modifications. The classification of seeds followed Perez-Cortez et al. (2002), except that the most ornamented region of the margin was considered, and the apex was more fully described. The measurements were performed using a digital caliper. The aryl was removed and the seeds were digitally photographed using a Leica M205C stereomicroscope with an attached DFC295 digital camera. Selected seeds were fixed to doublesided carbon tape and then metalized with a thin layer of palladium gold (ca. $150^{\circ}$ thickness) for three minutes and analyzed with a Jeol Model JSM 6390 scanning electron microscope of the Departamento de Invertebrados do Museu Nacional, Universidade Federal do Rio de Janeiro.

The principal component analysis (PCA) was performed on 42 variables (power $=0.5$, square root transformed) using the software PC-ORD 5.0 (McCune \& Mefford 2006). The variance-covariance matrix and biplot of distance were selected. The results are presented in a two-dimensional graph of the first and second principal components.

An identification key was developed using the principal morphological characters of the seeds.

\section{Results}

The seeds examined in this study are illustrated in Figures 2-9 and their measurements and morphological characters are presented, in Tables 1 and 2, respectively. The species analyzed were: Passiflora candida, Passiflora ceratocarpa, Passiflora costata, Passiflora elliptica, Passiflora engleriana, Passiflora faroana, Passiflora haematostigma, Passiflora hexagonocarpa, Passiflora longiracemosa, Passiflora macrophylla, Passiflora mansoi, Passiflora ovata, Passiflora pentagona, Passiflora pyrrhantha, Passiflora rhamnifolia, Passiflora rusbyi, Passiflora securiclata, Passiflora skiantha, Passiflora sphaerocarpa, Passiflora spinosa, Passiflora tessmannii, Passiflora tica, Passiflora venosa, Passiflora sp. 1 and Passiflora sp. 2.

The seeds varied in length $(3.85-14.82 \mathrm{~mm})$, width (2.68-8.62 mm) and thickness (1.03-4.33 mm) (Tab. 1). The species Passiflora rusbyi stood out as having the longest $(14.82 \mathrm{~mm})$, widest $(8.62 \mathrm{~mm})$ and thickest $(4.33 \mathrm{~mm})$ seeds. Passiflora tica had the shortest $(3.85 \mathrm{~mm})$ and thinnest seeds, while Passiflora hexagonocarpa, had the narrowest (2.68 mm) (Tab. 1).

Eight types of ornamentation were found: reticulate (Fig. 8A), coarsely reticulate (Fig. 8B), reticulate-foveolate (Fig. 8C), reticulate-foveolate with a single central foveola costate toward the margin (Fig. 8D), reticulate-alveolate (Fig. 8E) (with homogeneous or heterogeneous alveola), transversely costate (Fig. 8F), transversely costate toward the margin (fig. 8G) and scrobiculate (Fig. 8H). The margins varied among crestate (Fig. 8I), dentate (Fig. 8J), parted (Fig. $8 \mathrm{~K}$ ), entire and parted-crestate (Fig. 8M).

The seed apex can be distinguished by the shape and position of the apical appendage (Tab. 2). Some species have the apical appendage positioned exactly on the apex of the seed, such as: $P$. costata, P. faroana, P. haematostigma, $P$. pyrrhantha, P. rhamnifolia, P. rusbyi, P. securiclata, P. skiantha,

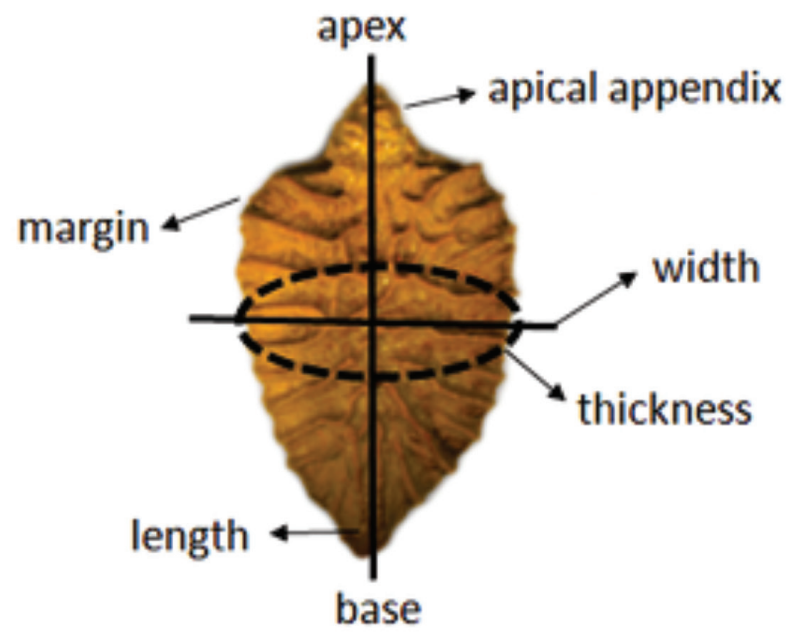

Figure 1. Photomicrographs of a seed showing the features and dimensions measured. 
Ana Carolina Mezzonato-Pires, Cláudia Barbieri Ferreira Mendonça, Michaele Alvim Milward-De-Azevedo and Vania Gonçalves-Esteves
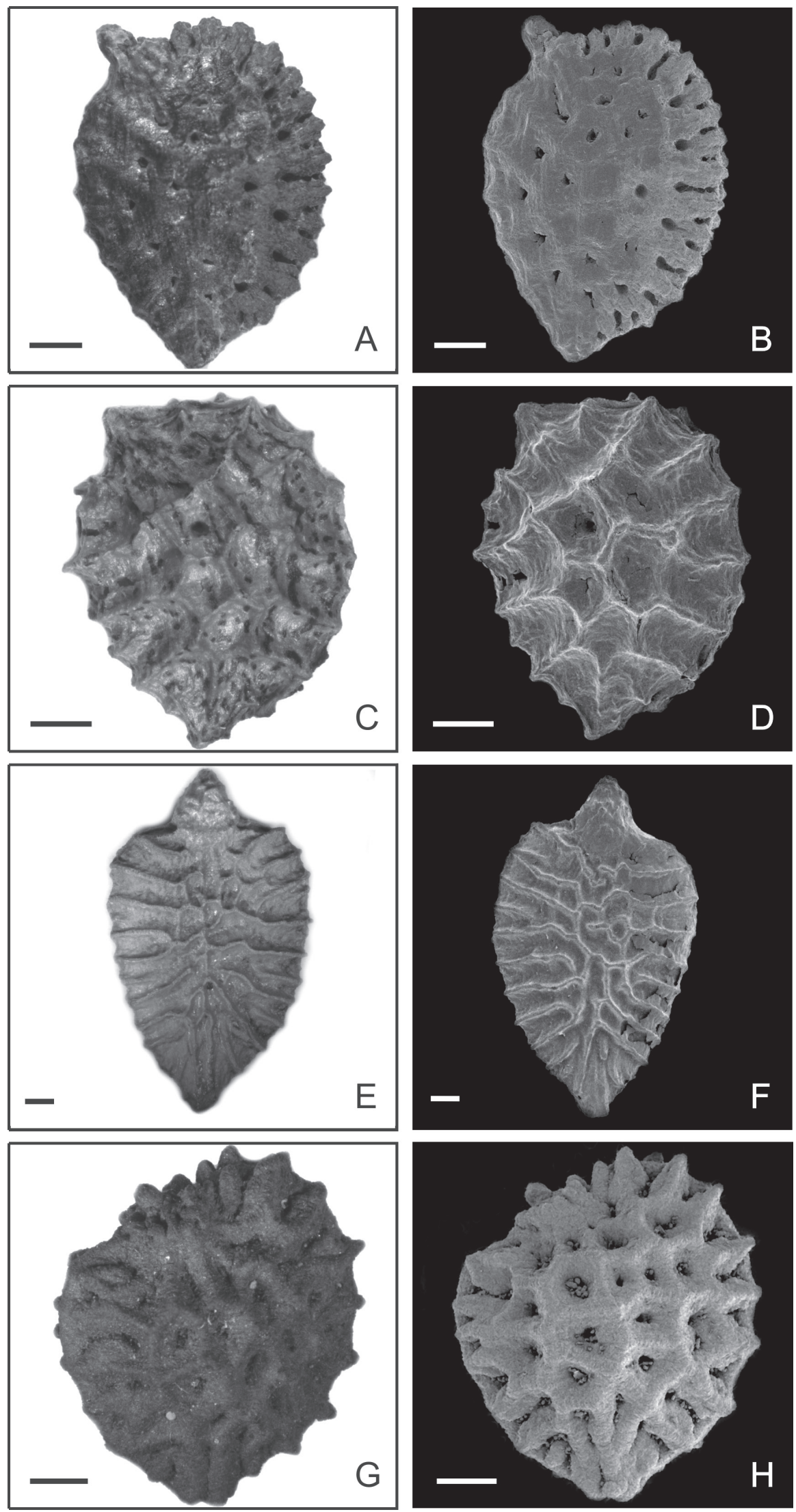

Figure 2. Photomicrographs and electron photomicrographs of seeds of the species of Passiflora subgenus Astrophea. A-B. P. candida. C-D. P. ceratocarpa. E-F. P. costata G-H. P. elliptica. Bar: $1 \mathrm{~mm}$. 

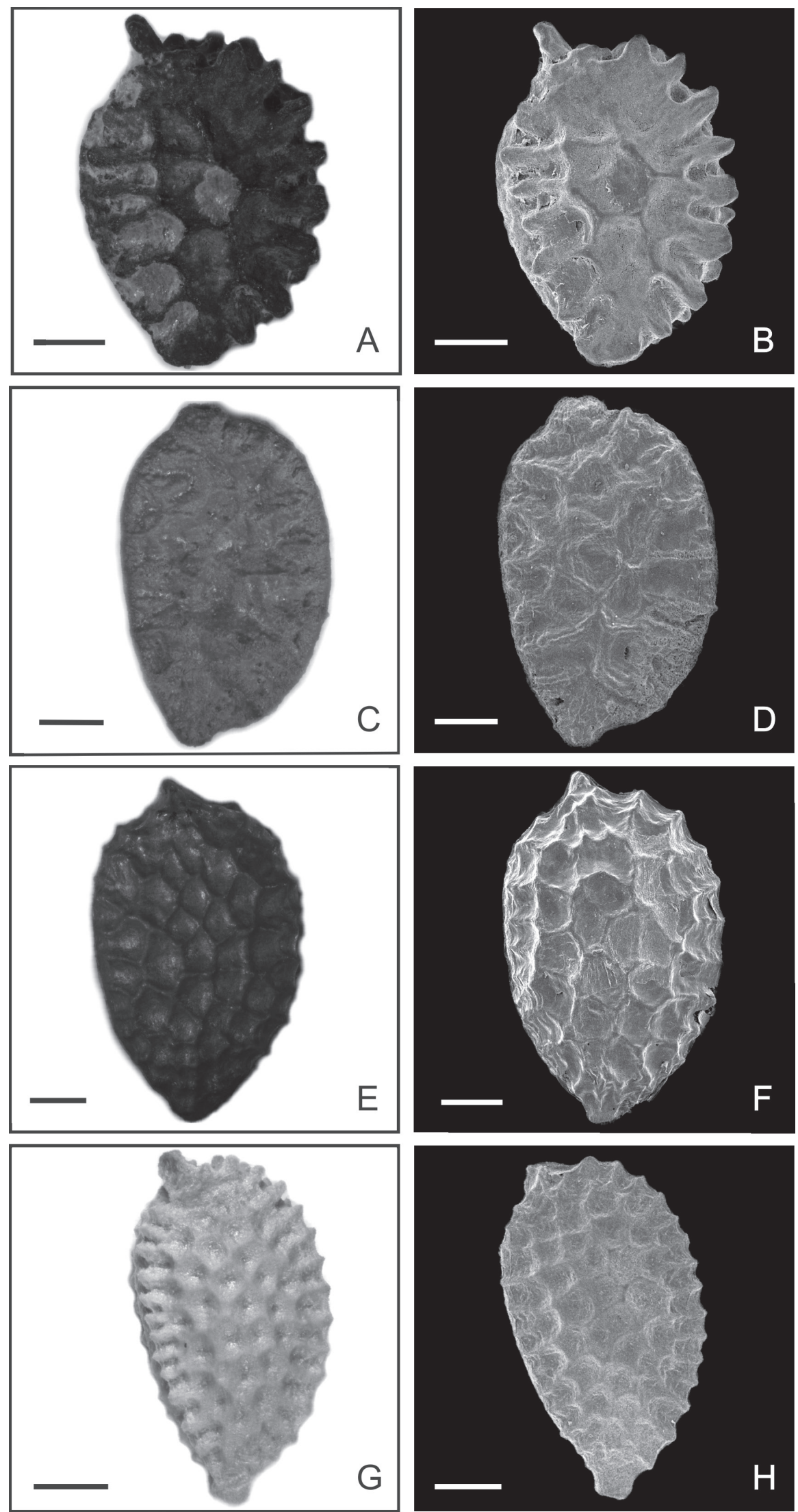

Figure 3. Photomicrographs and electron photomicrographs of seeds of the species of Passiflora subgenus Astrophea. A-B. P. engleriana. C-D. P. faroana. E-F. P. haematostigma. G-H. P. hexagonocarpa. Bar: $1 \mathrm{~mm}$. 
Ana Carolina Mezzonato-Pires, Cláudia Barbieri Ferreira Mendonça, Michaele Alvim Milward-De-Azevedo and Vania Gonçalves-Esteves
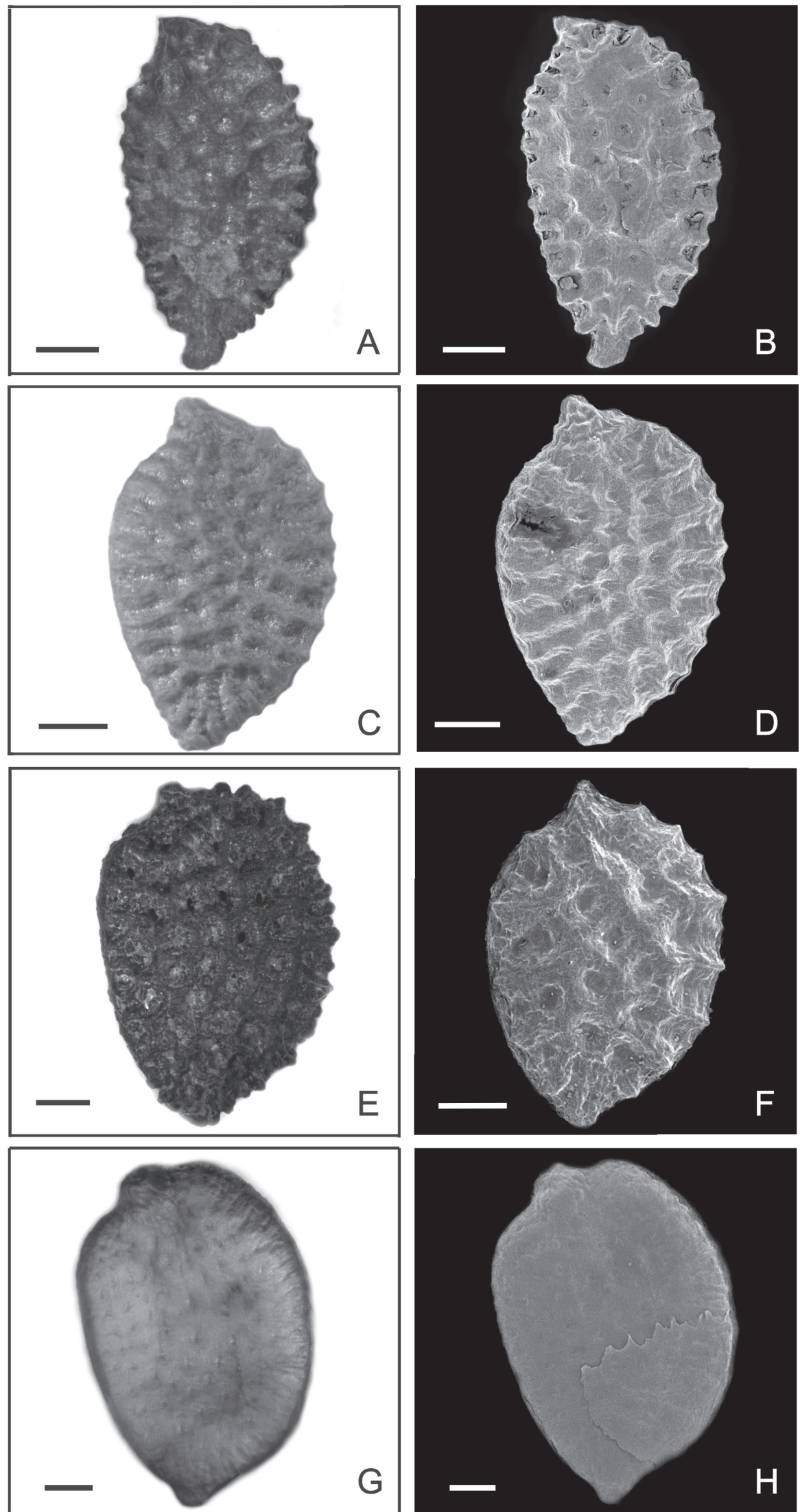

Figure 4. Photomicrographs and electron photomicrographs of seeds of the species of Passiflora subgenus Astrophea. A-B. P. longiracemosa. C-D. P. macrophylla. E-F. P. mansoi.G-H. P. ovata RB552847. Bar: $1 \mathrm{~mm}$. 

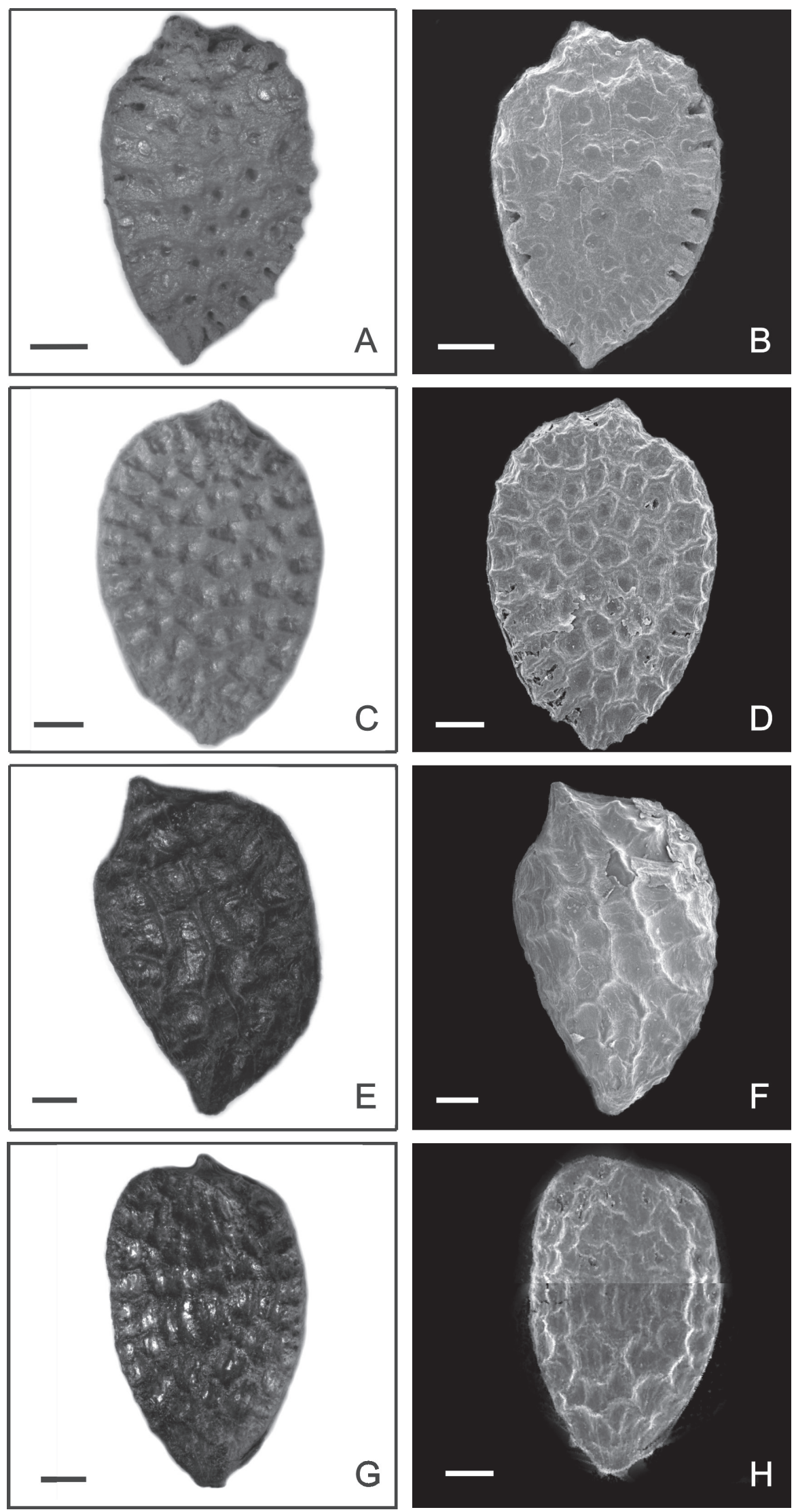

Figure 5. Photomicrographs and electron photomicrographs of seeds of the species of Passiflora subgenus Astrophea. A-B. P. pentagona. C-D. P. pyrrhantha. E-F. P. rhamnifolia. G-H. P. rusbyi. Bar: $1 \mathrm{~mm}$ (A-E). $2 \mathrm{~mm}$ (G-H). 
Ana Carolina Mezzonato-Pires, Cláudia Barbieri Ferreira Mendonça, Michaele Alvim Milward-De-Azevedo and Vania Gonçalves-Esteves
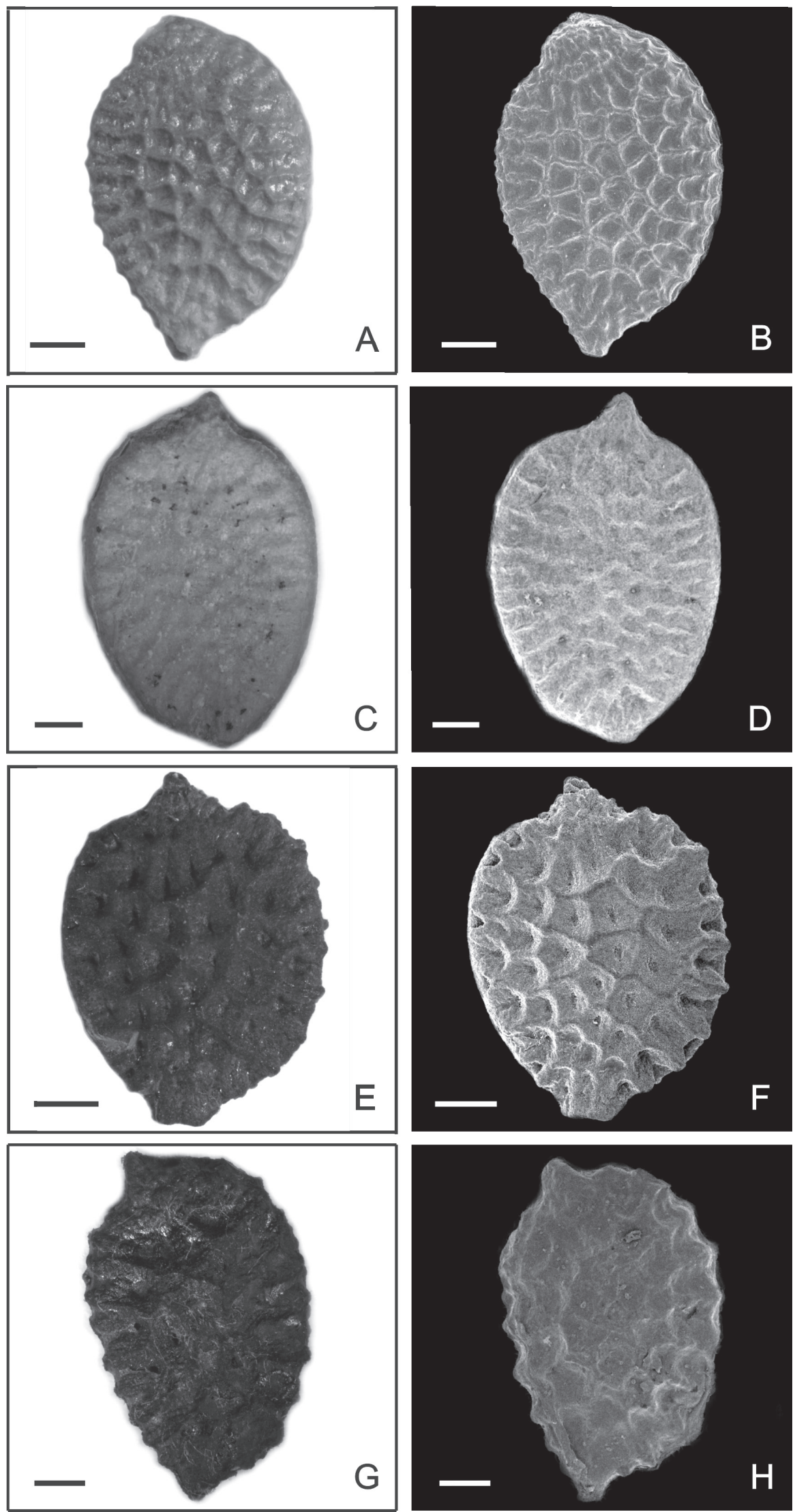

Figure 6. Photomicrographs and electron photomicrographs of seeds of the species of Passiflora subgenus Astrophea. A-B. P. securiclata. C-D. P. skiantha. E-F. P. sphaerocarpa. G-H. P. spinosa. Bar: $1 \mathrm{~mm}$. 

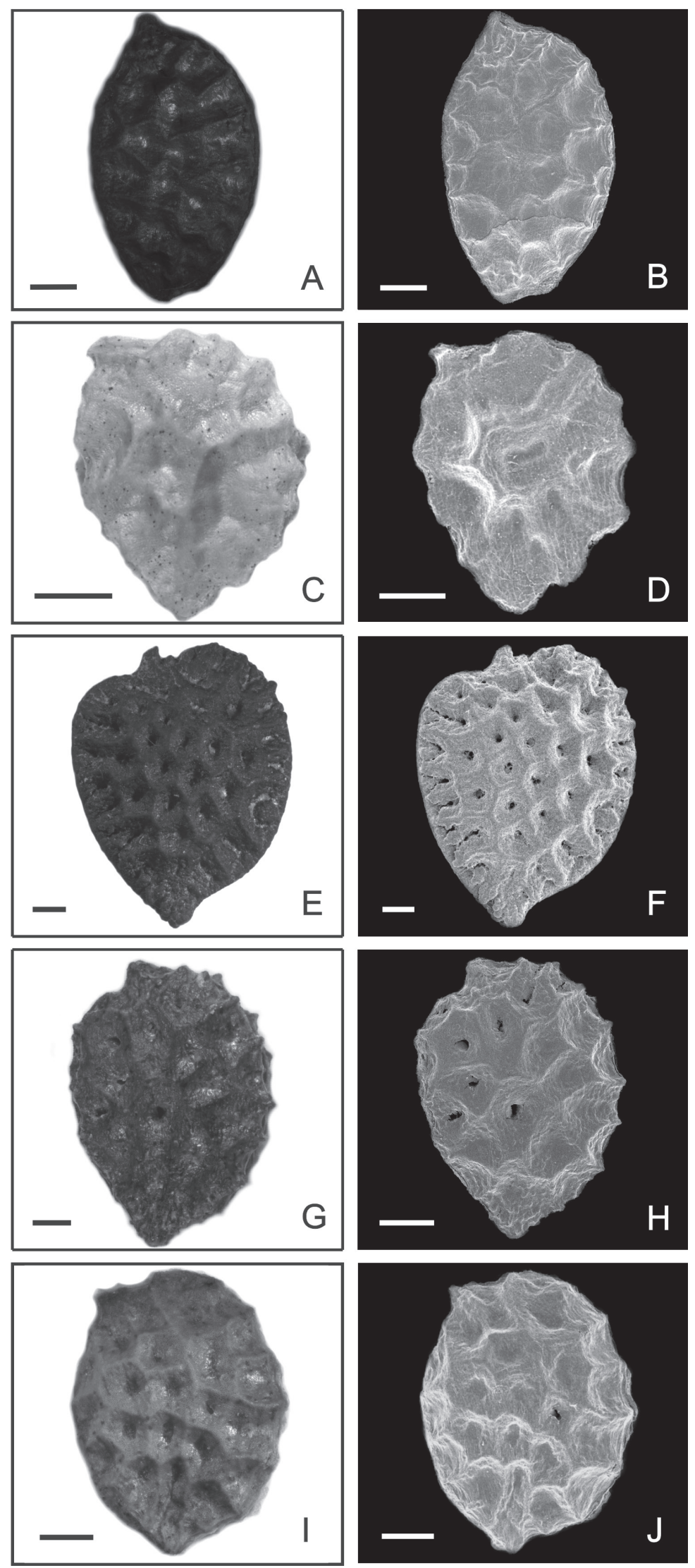

Figure 7. Photomicrographs and electron photomicrographs of seeds of the species of Passiflora subgenus Astrophea. A-B. P. tessmannii. C-D. P. tica. E-F. P. venosa. G-H. P. sp.1. I-J. P. sp. 2. Bar: $1 \mathrm{~mm}$. 

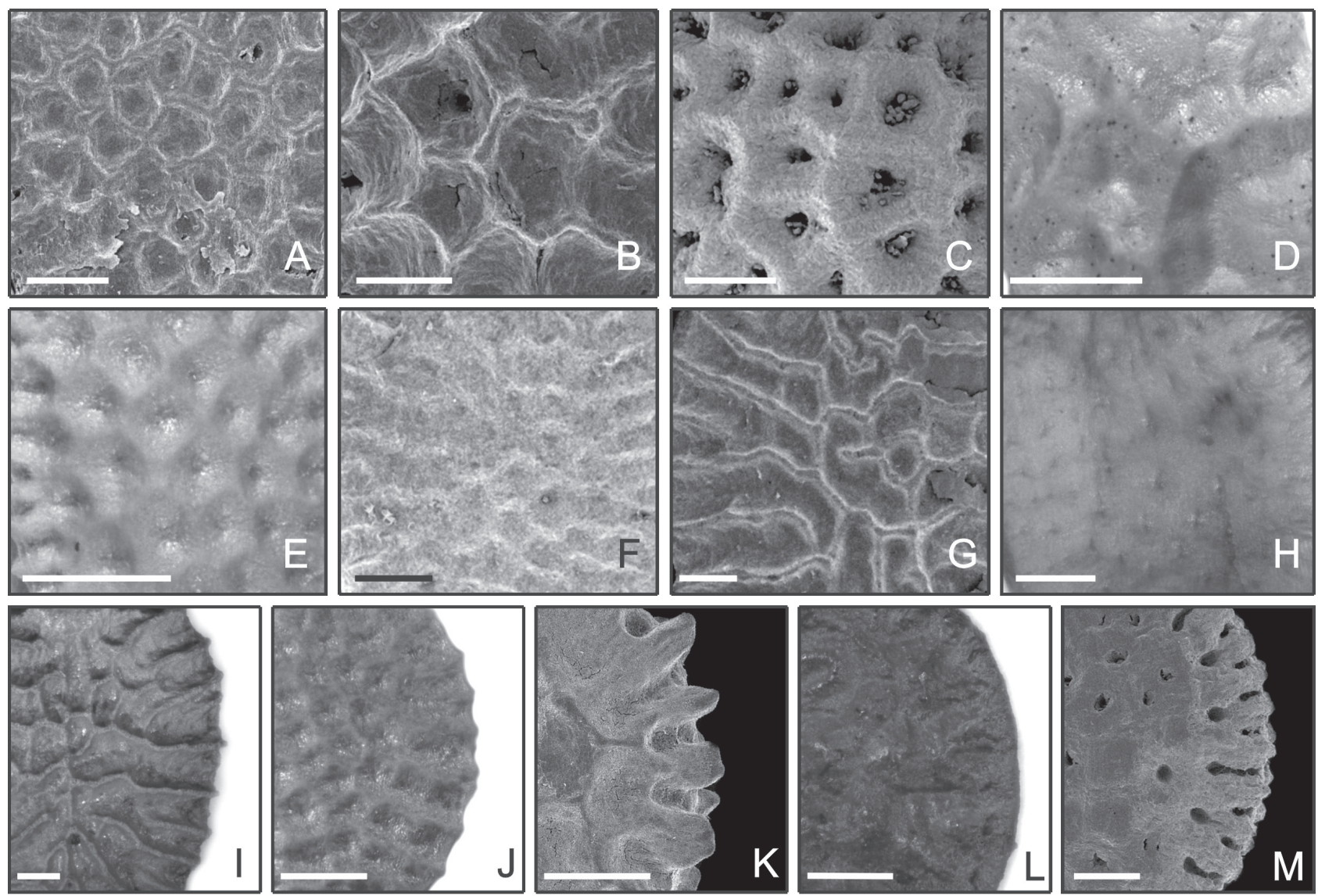

Figure 8. Photomicrographs and electron photomicrographs of ornamentation and margin of the seeds of the species of Passiflora subgenus Astrophea. Ornamentation: A. reticulate (P. pyrrhantha). B. coarsely reticulate (P. ceratocarpa). C. reticulate-foveolate (P. elliptica). D. reticulate-foveolate with a single central foveola costate toward the margin (P. tica). E. reticulate-alveolate (P. hexagonocarpa). F. transversely costate (P. skiantha). G. transversely costate toward the margin ( $P$. costata). H. scrobiculate (P. ovata). Margin: I. crestate (P. costata). J. dentate (P. macrophylla). K. parted (P. engleriana). L. entire (P. faroana). M. parted-crestate (P. pentagona). Bar: $1 \mathrm{~mm}$

P. sphaerocarpa, $P$. spinosa and $P$. venosa. The appendage of other species are positioned $10^{\circ}$ to $40^{\circ}$ from the apex and their shapes vary among: acute (Fig. 9A), acute with an evident elevated region (Fig. 9B), acute prominent (Fig. 9C), acute slightly prominent (Fig. 9D), acute-truncate (Fig. 9E), obtuse slightly prominent (Fig. 9F), truncated slightly prominent (Fig. 9G), fused (Fig. 9H) and inconspicuous (Fig. 9I) (Tab. 2). The seeds of the majority of species have an acute base (Fig. 9J), but others are rounded (Fig. 9K), cordate (Fig. 9L), truncate (Fig. 9M), obtuse (Fig. 9N) and truncate to slightly acute (Fig. 90).

The shape of the analyzed seeds (Tab. 2) varied among obovate, lanceolate, cordiform, and oblong to elliptical. The predominant shape in the majority of species was obovate, with the variation of narrowly obovate in only two species.

Considering only seed characters, it is apparent that there is great morphological variety within the Passiflora subg. Astrophea. The characteristics that varied most were surface ornamentation, shape of the apical appendage and size and condition of the margin. Thus, the description of seeds is very useful in the delimitation of species of this group, thereby assisting in the identification of specimens with only fruit.

All of the quantitateive and qualitative characters were used in a PCA. The results of the PCA explained $32.64 \%$ of the accumulative variance (Tab. 3 ). The first principal component explained $19.52 \%$ of the total variance, with the most significant characters being those of appendage displacement and the shape of the obtuse apex. Only species with seeds with a displaced appendage occurred on the positive side of Axis 1, whereas species with the appendage on the apex were on the negative side. Species with an obtuse seed apex were also grouped on the positive side of Axis 1. The second principal component explained $13.11 \%$ of the total variance, with the most significant character being the shape of the acute prominent appendage. All reticulate species were positioned on the negative side of Axis 2. The third principal component explained 9.71 $\%$ of the total variance, mainly through the character of obovate seed shape. 
Table 1. Measurements (in $\mathrm{mm}$ ) of the seeds of the species of Passiflora subgenus Astrophea.

\begin{tabular}{|c|c|c|c|}
\hline Species & Length & Width & Thickness \\
\hline P. candida (Figs. 2A, B) & 6.74 & 4.78 & 2.30 \\
\hline P. ceratocarpa (Figs. 2C, D, 8B, 9A) & 5.87 & 4.46 & 2.37 \\
\hline P. costata (Figs. 2E, F, 8I, 9C) & 11.00 & 6.90 & 1.84 \\
\hline P. elliptica (Figs. 2G, H, 8C, 9H) & 6.21 & 5.45 & 3.17 \\
\hline P. engleriana (Figs. 3A, B, 8K) & 4.97 & 3.39 & 1.55 \\
\hline P. faroana (Figs. 3C, D, 8L, 9G) & 5.20 & 3.51 & 1.60 \\
\hline P. haematostigma (Figs. 3E, F, 9O) & 6.12 & 3.71 & 1.68 \\
\hline P. hexagonocarpa (Figs. 3G, H, 8E, 9E) & 4.84 & 2.68 & 1.18 \\
\hline P. longiracemosa (Figs. 4A, B, 9M) & 5.68 & 2.99 & 1.39 \\
\hline P. macrophylla (Figs. 4C, D, 8J) & 5.11 & 3.32 & 1.07 \\
\hline P. mansoi (Figs. 4E, F, 9N) & 6.84 & 4.74 & 2.44 \\
\hline P. ovata (Figs. 4G, $\mathrm{H}, 8 \mathrm{H}$ ) & 7.56 & 4.85 & 1.14 \\
\hline P. pentagona (Figs. 5A, B, 8M, 9D) & 5.84 & 3.25 & 1.91 \\
\hline P. pyrrantha (Figs. 5C, D, 8A) & 7.29 & 4.58 & 1.12 \\
\hline P. rhamnifolia (Figs. 5E, F) & 7.73 & 4.49 & 2.07 \\
\hline P. rusbyi (Figs. 5G, H) & 14.82 & 8.62 & 4.33 \\
\hline P. securiclata (Figs. 6A, B, 9F) & 6.16 & 3.96 & 1.24 \\
\hline P. skiantha (Figs. 6C, D, 8F, 9K) & 7.70 & 4.84 & 1.31 \\
\hline P. sphaerocarpa (Figs. 6E, F, 9L) & 5.34 & 4.09 & 1.82 \\
\hline P. spinosa (Figs. 6G, H, 9J) & 6.82 & 4.41 & 1.87 \\
\hline P. tessmannii (Figs. 7A, B) & 6.21 & 3.76 & 1.24 \\
\hline P. tica (Figs. 7C, D, 8D) & 3.85 & 3.01 & 1.03 \\
\hline P. venosa (Figs.7E, F, 9B) & 8.18 & 6.44 & 2.93 \\
\hline P. sp. 1 (Figs. 7G, $\mathrm{H}$ ) & 5.49 & 3.81 & 1.80 \\
\hline P. sp. 2 (Figs. 7I, J, 9I) & 5.43 & 3.95 & 1.11 \\
\hline
\end{tabular}

Table 2. Morphological characterization of seeds of species of Passiflora subgenus Astrophea

\begin{tabular}{|c|c|c|c|c|c|}
\hline Species & Shape & Margin & Apex & Base & Ornamentation \\
\hline P. candida (Figs. 2A, B) & obovate & parted-crestate & $\begin{array}{l}\text { obtuse. with appendage acute } \\
\text { prominent. positioned to } 40^{\circ} \text { from } \\
\text { the apex }\end{array}$ & acute & reticulate-foveolate \\
\hline P. ceratocarpa (Figs. 2C, D, 8B, 9A) & obovate & crestate & $\begin{array}{l}\text { truncate. with appendage acute. } \\
\text { positioned to } 30^{\circ} \text { from the apex }\end{array}$ & acute & coarsely reticulate \\
\hline P. costata (Figs. 2E, F, 8I, 9C) & lanceolate & crestate & with appendage acute prominent & acute & $\begin{array}{l}\text { transversely costate } \\
\text { toward the margin }\end{array}$ \\
\hline P. elliptica (Figs. 2G, H, 8C, 9H) & cordiform & crestate & acute. with appendage fused & cordate & reticulate-foveolate \\
\hline P. engleriana (Figs. 3A, B, 8K) & obovate & parted & $\begin{array}{l}\text { obtuse. with appendage acute } \\
\text { prominent, positioned o } 20^{\circ} \\
\text { from the apex }\end{array}$ & truncate & $\begin{array}{l}\text { transversely costate } \\
\text { toward the margin }\end{array}$ \\
\hline P. faroana (Figs. 3C, D, 8L, 9G) & oblong & entire & $\begin{array}{l}\text { with appendage truncate slightly } \\
\text { prominent }\end{array}$ & obtuse & reticulate \\
\hline P. haematostigma (Figs. 3E, F, 9O) & obovate & dentate & $\begin{array}{l}\text { wth appendage acute slightly } \\
\text { prominent }\end{array}$ & $\begin{array}{l}\text { truncate to } \\
\text { slightly acute }\end{array}$ & reticulate \\
\hline P. hexagonocarpa (Figs. 3G, H, 8E, 9E) & $\begin{array}{l}\text { narrowly } \\
\text { obovate }\end{array}$ & parted-crestate & $\begin{array}{l}\text { acute. with appendage acute- } \\
\text { truncate positioned to } 30^{\circ} \text { from } \\
\text { the apex }\end{array}$ & truncate & $\begin{array}{l}\text { reticulate-alveolate. } \\
\text { alveola homogeneous }\end{array}$ \\
\hline P. longiracemosa (Figs. 4A, B, 9M) & $\begin{array}{l}\text { narrowly } \\
\text { obovate }\end{array}$ & parted-crestate & $\begin{array}{l}\text { obtuse. with appendage acute } \\
\text { slightly prominent. positioned to } \\
20^{\circ} \text { from the apex }\end{array}$ & truncate & $\begin{array}{l}\text { reticulate-alveolate. } \\
\text { alveola heterogeneous }\end{array}$ \\
\hline P. macrophylla (Figs. 4C, D, 8J) & obovate & dentate & $\begin{array}{l}\text { obtuse. with appendage acute } \\
\text { slightly prominent. positioned to } \\
20^{\circ} \text { from the apex }\end{array}$ & obtuse & reticulate \\
\hline
\end{tabular}


Ana Carolina Mezzonato-Pires, Cláudia Barbieri Ferreira Mendonça,

Michaele Alvim Milward-De-Azevedo and Vania Gonçalves-Esteves

Table 2. Cont.

\begin{tabular}{|c|c|c|c|c|c|}
\hline Species & Shape & Margin & Apex & Base & Ornamentation \\
\hline P. mansoi (Figs. 4E, F, 9N) & obovate & crestate & $\begin{array}{l}\text { obtuse. with appendage acute } \\
\text { slightly prominent. positioned to } \\
20^{\circ} \text { from the apex }\end{array}$ & obtuse & reticulate-foveolate \\
\hline P. ovata (Figs. $4 \mathrm{G}, \mathrm{H}, 8 \mathrm{H}$ ) & oblong & entire & $\begin{array}{l}\text { obtuse. with appendage truncate } \\
\text { slightly prominent. positioned to } \\
30^{\circ} \text { from the apex }\end{array}$ & acute & scrobiculate \\
\hline P. pentagona (Figs. 5A, B, 8M, 9D) & obovate & parted & $\begin{array}{l}\text { obtuse. with appendage acute } \\
\text { slightly prominent. positioned to } \\
20^{\circ} \text { from the apex }\end{array}$ & acute & reticulate-foveolate \\
\hline P. pyrrantha (Figs. 5C, D, 8A) & obovate & entire & $\begin{array}{l}\text { with appendage obtuse slightly } \\
\text { prominent }\end{array}$ & obtuse & reticulate \\
\hline P. rhamnifolia (Figs. 5E, F) & obovate & entire & with appendage acute & obtuse & reticulate \\
\hline P. rusbyi (Figs. 5G, H) & obovate & entire & $\begin{array}{l}\text { with appendage acute slightly } \\
\text { prominent }\end{array}$ & truncate & reticulate \\
\hline P. securiclata (Figs. 6A, B, 9F) & obovate & dentate & $\begin{array}{l}\text { with appendage obtuse slightly } \\
\text { prominent }\end{array}$ & truncate & reticulate \\
\hline P. skiantha (Figs. 6C, D, 8F, 9K) & oblong & entire & with appendage acute prominent & rounded & transversely costate \\
\hline P. sphaerocarpa (Figs. 6E, F, 9L) & cordiform & parted & with appendage acute prominent & cordate & reticulate-alveolate \\
\hline P. spinosa (Figs. 6G, H, 9J) & obovate & dentate & $\begin{array}{l}\text { with appendage acute slightly } \\
\text { prominent }\end{array}$ & acute & reticulate-foveolate \\
\hline P. tessmannii (Figs. 7A, B) & elliptical & entire & $\begin{array}{l}\text { obtuse. with appendage acute } \\
\text { slightly prominent. positioned to } \\
20^{\circ} \text { from the apex }\end{array}$ & lightly cordate & reticulate \\
\hline P. tica (Figs. 7C, D, 8D) & cordiform & dentate & $\begin{array}{l}\text { obtuse. with appendage acute } \\
\text { prominent. positioned to } 40^{\circ} \text { from } \\
\text { the apex }\end{array}$ & acute & $\begin{array}{c}\text { reticulate-foveolate } \\
\text { with a single central } \\
\text { foveola costate toward } \\
\text { the margin }\end{array}$ \\
\hline P. venosa (Figs.7E, F, 9B) & cordiform & entire & $\begin{array}{l}\text { with appendage acute with an } \\
\text { evident elevated region }\end{array}$ & acute & reticulate-alveolate \\
\hline P. sp. 1 (Figs. 7G, H) & obovate & dentate & $\begin{array}{l}\text { obtuse. with appendage acute } \\
\text { slightly prominent. positioned to } \\
10^{\circ} \text { from the apex }\end{array}$ & acute & reticulate \\
\hline P. sp. 2 (Figs. 7I, J, 9I) & elliptical & slightly dentate & $\begin{array}{l}\text { obtuse. with appendage } \\
\text { inconspicuous. positioned to } 40^{\circ} \\
\text { from the apex }\end{array}$ & acute & reticulate-alveolate \\
\hline
\end{tabular}

Table 3. Cumulative variance and vectores values of principal component analysis (PCA) using palinological characters of 25 táxons of Passiflora subgenus Astrophea.

\begin{tabular}{|c|c|c|c|}
\hline Axis of the principal component & 1 & 2 & 3 \\
\hline Cumulative variance [\%] & 32.647 & 19.528 & 13.119 \\
\hline Characters & \multicolumn{3}{|c|}{ Axis } \\
\hline Length & -0.226 & 0.0156 & 0.1798 \\
\hline Width & -0.1561 & 0.0816 & 0.2012 \\
\hline Thickness & -0.0581 & 0.0447 & 0.1843 \\
\hline Shape obovate & -0.0153 & -0.4270 & 0.3568 \\
\hline Shape narrowly obovate & 0.0818 & 0.0448 & -0.2482 \\
\hline Shape lanceolate & -0.0303 & 0.0803 & 0.0977 \\
\hline Shape cordiform & 0.0133 & 0.2701 & 0.0208 \\
\hline Shape oblong & -0.0970 & 0.0911 & -0.1282 \\
\hline Shape elliptical & 0.0476 & -0.0593 & -0.0990 \\
\hline Margin crestate & 0.0445 & 0.1460 & 0.2725 \\
\hline Margin dentate & 0.0785 & -0.2670 & 0.0798 \\
\hline
\end{tabular}


Table 3. Cont.

\begin{tabular}{|c|c|c|c|}
\hline Axis of the principal component & 1 & 2 & 3 \\
\hline Cumulative variance [\%] & 32.647 & 19.528 & 13.119 \\
\hline Characters & \multicolumn{3}{|c|}{ Axis } \\
\hline Margin entire & -0.3153 & 0.0134 & -0.1933 \\
\hline Margin parted-crestate & 0.1250 & 0.0364 & -0.1965 \\
\hline Apppendage on the apex & -0.4695 & 0.0340 & 0.0873 \\
\hline Apppendage displaced & 0.4695 & -0.0340 & -0.0873 \\
\hline Shape of apex obtuse & 0.3928 & -0.1881 & -0.0674 \\
\hline Shape of apex truncate & 0.0226 & 0.0408 & 0.0934 \\
\hline Shape of apex acute & 0.0541 & 0.1133 & -0.1133 \\
\hline Shape of appendage acute & -0.0184 & -0.0462 & 0.0476 \\
\hline Shape of appendage acute prominent & 0.0066 & 0.3254 & 0.1507 \\
\hline Shape of appendage acute slightly prominent & 0.1082 & -0.3766 & 0.0687 \\
\hline Shape of appendage acute with an evident elevated region & -0.0387 & 0.0730 & 0.0096 \\
\hline Shape of appendage acute-truncate & 0.0335 & 0.0444 & -0.1376 \\
\hline Shape of appendage obtuse slightly prominent & -0.1018 & -0.0894 & -0.0333 \\
\hline Shape of appendage truncate slightly prominent & -0.0448 & 0.0277 & -0.1055 \\
\hline Shape of appendage fused & 0.0206 & 0.0689 & 0.0243 \\
\hline Shape of appendage inconspicuous & 0.0347 & -0.0273 & -0.0243 \\
\hline Base acute & 0.1861 & 0.1313 & 0.3784 \\
\hline Base cordate & 0.0149 & 0.1247 & -0.0700 \\
\hline Base truncate & 0.0115 & -0.0299 & -0.2470 \\
\hline Base obtuse & -0.1291 & -0.2215 & -0.0554 \\
\hline Base truncate to slightly acute & -0.0312 & -0.0680 & 0.0167 \\
\hline Base rounded & -0.0522 & 0.0634 & -0.0227 \\
\hline Reticulate & -0.2500 & -0.3921 & -0.1891 \\
\hline Coarsely reticulate & 0.0226 & 0.0408 & 0.0934 \\
\hline Reticulate-foveolate & 0.1375 & -0.0455 & 0.2883 \\
\hline $\begin{array}{l}\text { Reticulate-foveolate with a single central foveola costate } \\
\text { toward the margin }\end{array}$ & 0.0499 & 0.0404 & 0.0065 \\
\hline Reticulate-alveolate & 0.0727 & 0.1692 & -0.2361 \\
\hline Transversely costate & -0.522 & 0.0634 & -0.0227 \\
\hline Transversely costate toward the margin & 0.0049 & 0.0930 & 0.0930 \\
\hline Scrobiculate & 0.0146 & 0.0309 & -0.0333 \\
\hline
\end{tabular}

In the two-dimensional graph of the PCA (Fig. 10), it can be seen that the species P. pentagona, P. tica and $P$. longiracemosa have the highest values on the first principal component and P. sphaerocarpa, P. costata and P. venosa, on the second. Passiflora rusbyi, P. pyrrhantha and P. rhamnifolia have the lowest values on the first principal component and P. macrophylla, P. haematostigma and P. securiclata on the second.

\section{Key based on seed characters for species identification of the Passiflora subg. Astrophea}

1. Seeds with surface transversely costate

2. Shape lanceolate, margin crestate (Figs. 2E, F, 8I, 9C) P. costata

2'. Shape obovate, oblong, margin parted or entire

3. Appendage in the seed apex, rounded base (Figs. 6C, D, 8F, 9K) P. skiantha

3 '. Appendage positioned $20^{\circ}$ from the seed apex, truncate base (Figs. 3A, B, 8K) P. engleriana 1 '. Seeds with surface no transversely costate

4. Surface scrobiculate (Figs. 4G, H, 8H) P. ovata 4'. Surface reticulate, coarsely reticulate, reticulate-foveolate, reticulate-foveolate with a single central foveola costate toward the margin or reticulate-alveolate

5. Seed base cordate to slightly cordate

6. Shape elliptical (Figs. 7A, B)

6'. Shape cordiform

7. Surface reticulate-alveolate, apex with acute prominent appendage (Figs. 6E, F, 9L) P. sphaerocarpa 
7'. Surface reticulate-foveolate, apex acute with fused appendage (Figs. 2G, H, 8C, 9H) ..P. elliptica

5 '. Seed base acute, truncate or obtuse

8. Margin entire

9. Appendage truncate (Figs. 3C, D, 8L, 9G)

P. faroana

9'. Appendage no truncate

10. Shape cordiforme (Figs.7E, F, 9B)

P. venosa

10'. Shape obovate, narrowly obovate or elliptical

11. Base truncate (Figs. 5G, H)

11'. Base obtuse

12. Appendage acute (Figs. 5E, F)

P. rhamnifolia

12'. Appendage obtuse (Figs. 5C, D, 8A)

8'. Margin crestate, parted-crestate, parted or dentate

13. Surface reticulate or coarsely reticulate

14. Margin crestate (Figs. 2C, D, 8B, 9A) ...

P. ceratocarpa

14'. Margin dentate

15. Shape elliptical (Figs. 7I, J, 9I)

P. sp. 2

15'. Shape obovate

16. Base obtuse, appendage displaced (Figs. 4C, D, 8J)

P. macrophylla

16'. Base truncate to slightly acute, appendage at the apex

17. Appendage acute (Figs. 3E, F, 9O).P. haematostigma

17'. Appendage obtuse (Figs. 6A, B, 9F)

P. securiclata

13'. Surface reticulate-foveolate or reticulate-alveolate

18. Base truncate, shape narrowly obovate

19. Appendage acute-truncate, alveola homogeneous (Figs. 3G, H, 8E, 9E)

19'. Appendage acute slightly prominent, alveola heterogeneous (Figs. 4A, B, 9M)

18 . Base acute or obtuse, shape obovate or cordiform

20. Appendage acute prominent

21. Shape cordiform, dimensions $3,85 \times 30,1 \times 1,03 \mathrm{~mm}$ (Figs. 7C, D, 8D) P. tica

21 '. Shape obovate, dimensions $6,74 \times 4,78 \times 2,30 \mathrm{~mm}$ (Figs. 2A, B) P. candida

20'. Appendage acute slightly prominent

22. Margin dentate

23. Surface reticulate-foveolate (Figs. 6G, H, 9J) P. spinosa

23'. Surface reticulate-alveolate (Figs. 7G, H P. sp. 1

22'. Margin partite or crestate

24. Base obtuse, dimensions $6,84 \times 4,74 \times 2,44 \mathrm{~mm}$ (Figs. 4E, F, 9N) P. mansoi

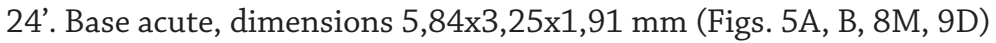

P. pentagona

\section{Discussion}

Among the species of the Passiflora subgenus Astrophea described by Killip (1938), the seeds were briefly described for seven: P. ceratocarpa, P. elliptica, P. faroana, P. hexagonocarpa, P. longiracemosa, P. pentagona and P. skiantha. The results presented by Killip (1938) were corroborated here for the species $P$. ceratocarpa with regard to seed shape, while for $P$. skiantha and P. pentagona, the shape described here was oblong and obovate, respectively. Passiflora elliptica was described by Killip (1938) as widely ovate and coarsely reticulate while the present study found it to be cordiform and reticulate-foveolate. For the species $P$. faroana, $P$. hexagonocarpa and $P$. longiracemosa, the results found here differ from those of Killip (1938) with regard to seed ornamentation. These differences seems to be due to an error in species identifications since the ornamentation is clearly reticulate or reticulate-alveolate.
The seeds of $P$. costata, P. lindeniana, P. mansoi and $P$. spinosa were studied by Pérez-Cortéz et al. (2002), in a work that only addressed morphological characters of seeds. Among these species only P. lindeniana was not included in the present study because of the lack of available material. Here $P$. costata was found to be longer and thinner than that presented by Pérez-Cortéz et al. (2002), whereas the results for $P$. mansoi and $P$. spinosa were very similar for those of Pérez-Cortéz et al. (2002). There was disagreement between the present study and Pérez-Cortéz et al. (2002), in the seed shape described for P. costata. Pérez-Cortéz et al. (2002) described the seeds of $P$. costata as elliptical with an obtuse base and reticulate-crestate ornamentation, whereas the present study found the seeds to be lanceolate with an acute base and transversely costate ornamentation towards the margin. We believe that this variation is a result of the wide geographic distribution of this species, which may have allowed morphological divergence in seeds due to varying 

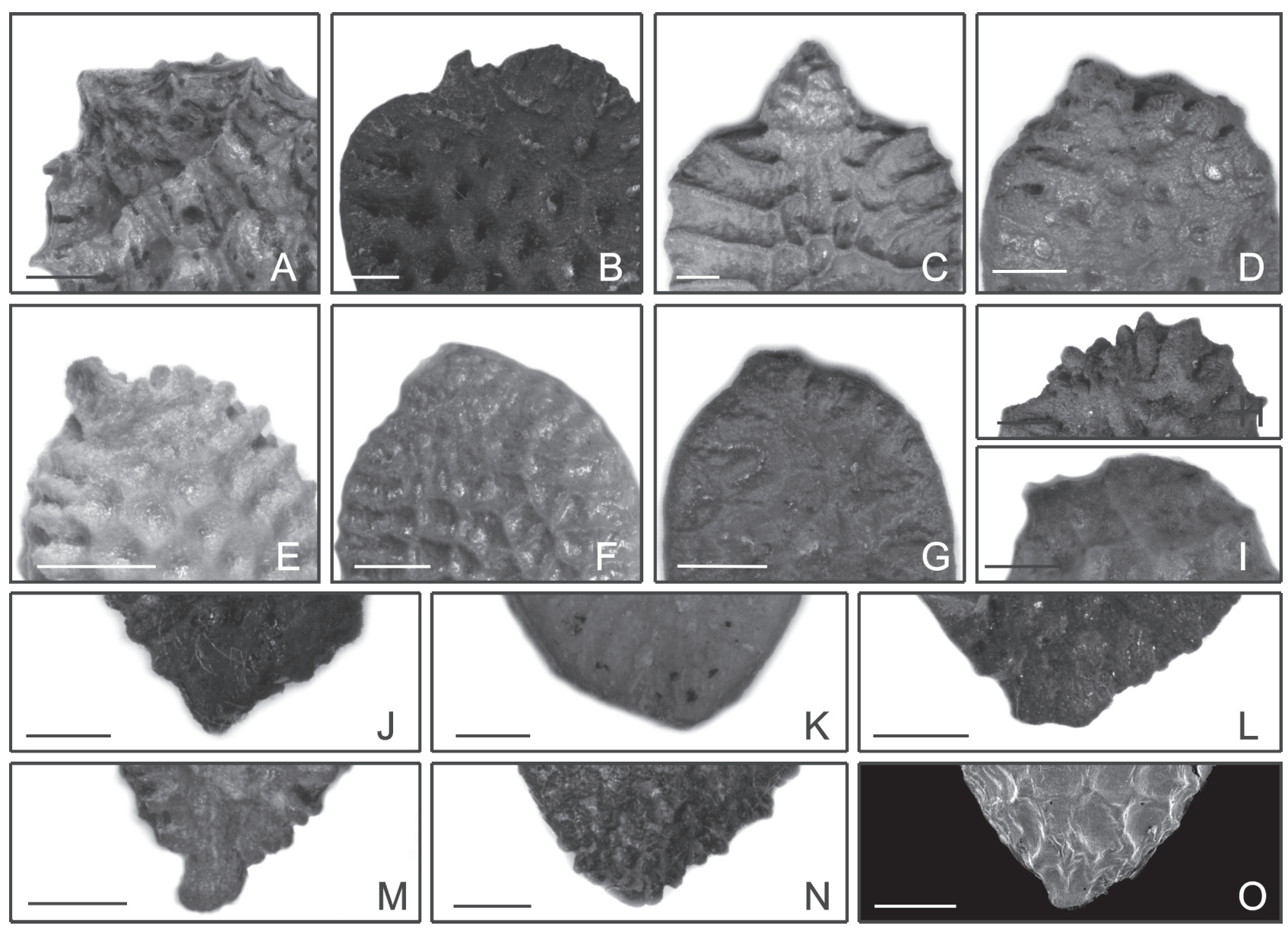

Figure 9. Photomicrographs and electron photomicrographs of apical appendage and base of the seeds of the species of Passiflora subgenus Astrophea. Apical appendage: A. acute (P. ceratocarpa). B. acute with an evident elevated region ( $P$. venosa). C. acute prominent $(P$. costata). D. acute slightly prominent (P. pentagona). E. acute-truncate (P. hexagonocarpa). F. obtuse slightly prominent (P. securiclata). G. truncate slightly prominent (P. faroana). H. fused (P. elliptica). I. inconspicuous (P. sp. 2). Base: J. acute (P. spinosa). K. rounded (P. skiantha). L. cordate (P. sphaerocarpa). M. truncate (P. longiracemosa). N. obtuse (P. mansoi). O. truncated to slightly acute ( $P$. haematostigma). Bar: $1 \mathrm{~mm}$

environments. The seed of $P$. mansoi was described by this same author as elliptical and with an entire margin; only the obtuse base and reticulate-alveolate ornamentation are corroborated by our results. The shape of the seed of $P$. spinosa was described as elliptical, and the margin crestate and the ornamentation reticulate-alveolate, thus, only the acute base was consistent with our findings. The apex was described in a different manner in our study, which we think is more detailed and understandable than that by Pérez-Cortéz et al. (2002), who described the seeds of these three species as simply with a "single horn". These differences may be explained by the fact that $P$. spinosa is part of a taxonomic complex, and the variation seen in the seeds may be because the material analyzed by these authors may not have been P. spinosa, but another species of the complex.

Pérez-Cortéz et al. (2005; 2009) studied the anatomy of the seed cover for a total of 15 species of the Passiflora subgenus Passiflora. Eight species were analyzed in 2005 and seven in 2009, but only in the 2009 publication did they describe the type of surface ornamentation, including reticulate, reticulate-foveolate and scrobiculate. These types of surface ornamentation were also found in the seeds of the $P$. subg. Astrophea, thereby demonstrating a degree of similarity between the two subgenera.

The seeds of the Brazilian species of the Passiflora subgenus Decaloba were described by Milward-de-Azevedo et al. (2012) and, when compared to the seeds of the Passiflora subgenus Astrophea analyzed here, are shorter and narrower (thickness was not measured). The shape varied from elliptical to obovate in most of the seeds, with the surface ornamentation having transverse striations with the number of striations varying from 5 to 11 in the majority of the species. This type of ornamentation was not found in any species of the Passiflora subg. Astrophea. Only two species of the Passiflora subgenus Decaloba did not have surface ornamentation with transverse striations, in which case they were described as foveolate and irregularly sulcate, the latter not found among the species studied in the present work. 


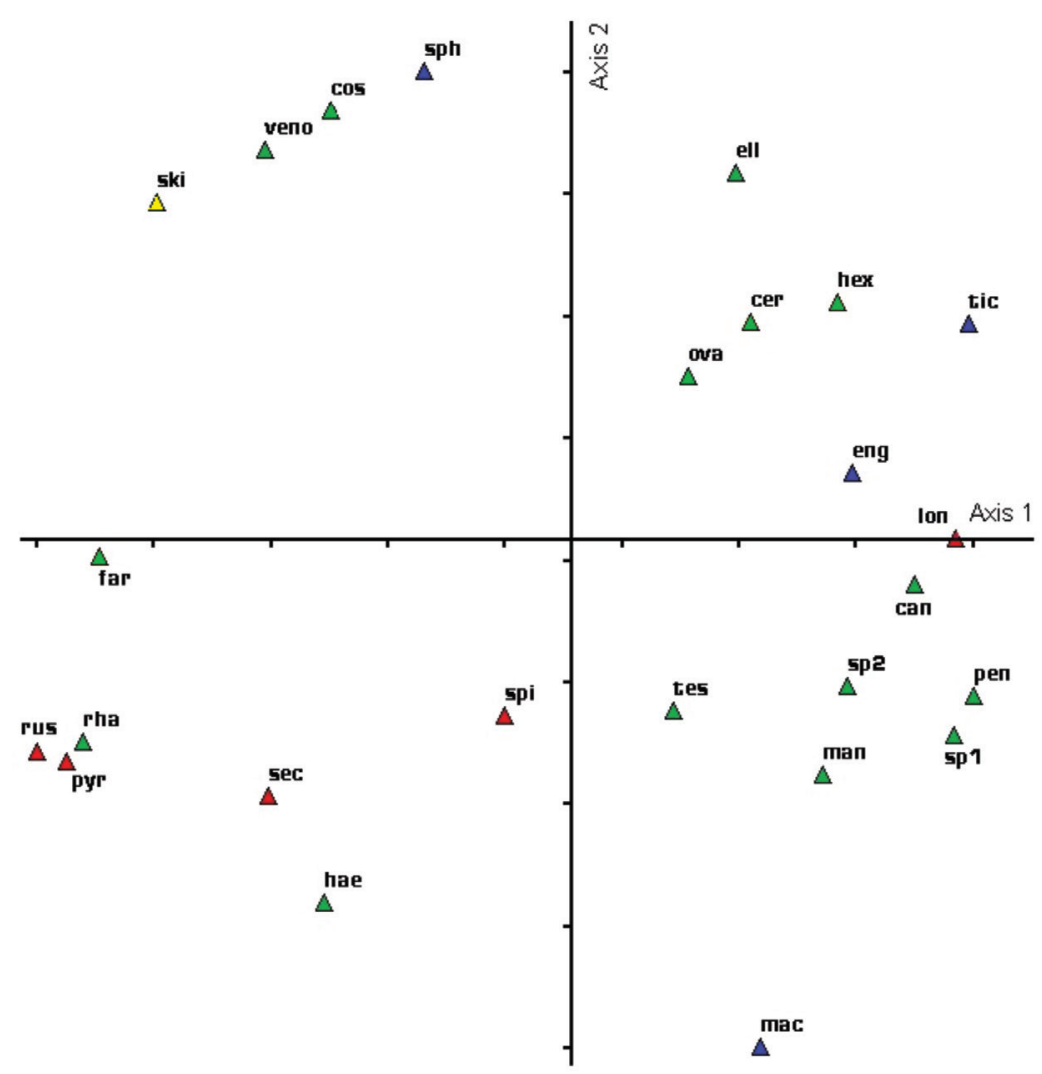

Figure 10. Principal component analysis performed with the seeds variables from Passiflora subgenus Astrophea. Species names are abbreviated with the first three letters of the epithet. The colors represent the sections of subgenus Astrophea. blue. section Astrophea; yellow. section Capreolata; green. section Pseudoastrophea; red. section Botryastrophea. Abrreviations: can. candida; cer. ceratocarpa; cos. costata; ell. elliptica; eng. engleriana; far. faroana; hae. haematostigma; hex. hexagonocarpa; lon. longiracemosa; mac. macrophylla; man. mansoi; ova. ovata; pen. pentagona; pyr. pyrrhantha; rha. rhamnifolia; rus. rusbyi; sec. securiclata; ski. skiantha; sph. sphaerocarpa; spi. spinosa; tes. tessmannii; tic. tica; ven. venosa. Please see the PDF version for color reference.

Passiflora subgenus Passiflora was studied by Cervi (1997) and among the 50 species treated, 36 had their seeds described, and most of those had their shape, size (length and width) and surface ornamentation mentioned. The shape of the seeds of this group presented greater variation than the subgenera Astrophea and Decaloba: obcordate, suborbiculate, "cordate", "cordate"-oblong, ovate, obovate and oblong-obcordate. The seeds were smaller than for the Passiflora subg. Astrophea and most species had foveolate and non-reticulate ornamentation, like most species of this work.

The PCA analysis revealed an evident delimitation of the taxa of the Passiflora subgenus Astrophea pointing to important characters for their separation, such as the location of the appendage on the apex or displaced from the apex. Species that have often been difficult to delimit because of very tenuous characters, such as $P$. rhamnifolia and $P$. pentagona, were positioned individually on the graph, showing the separation of these species. Furthermore, the poorly known and collected species $P$. elliptica, of which there are few fertile specimens, has often been confused with P. rhamnifolia and P. pentagona, however, the PCA analysis demonstrates that it is spatially distanced from them, thereby confirming its identity.

Despite these results, the seed characters do not support the current taxonomic classification of Feuillet \& MacDougal (2003), as can easily be seen by color-coding the symbols for each species in the PCA plot. The section Astrophea, which was the only section of the genus Passiflora that had tree species, was represented by seeds of four species ( $P$. engleriana, P. macrophylla, P. sphaerocarpa and P. tica), and each one of these had a different surface ornamentation. The section Capreolata was represented by one species ( $P$. skiantha). Fifteen species of the section Pseudoastrophea were studied (P. candida, P. ceratocarpa, P. costata, P. elliptica, P. faroana, P. haematostigma, P. hexagonocarpa, P. mansoi, $P$. ovata, P. pentagona, P. rhamnifolia, P. tessmannii, P. venosa, and $P$. sp. 1 and P. sp. 2), making it the most representative section and, not surprisingly, having most types of surface ornamentation being represented. Five species $(P$. longiracemosa, . pyrrhantha, $P$. rusbyi, $P$. securiclata and $P$. spinosa) belong to the section Botryastrophea and exhibited three different types of surface ornamentation. These results demonstrate clearly that the great morphological diversity among the seeds within the genus Passiflora do not support its current infrageneric taxonomic classification. 


\section{Conclusion}

Morphological characters of seeds are a new tool for delimiting taxa with quite conflicting morphological boundaries, as seen here with the Passiflora subgenus Astrophea and especially for the identification of specimens with only fruits and, consequently, seeds. In addition to the great taxonomic importance of this work, it will likely provide valuable contributions studies of phylogeny, archaeology, paleobotany, agriculture and horticulture as well.

\section{Acknowledgements}

The authors express their gratitude to curators of the herbaria that were visited and those that sent us material for this study and Amanda Soares who helped with the photomicrographs. The first author extends her thanks to the National Council for Scientific and Technological Development (CNPq) for the Doctoral Grant, and also to Research Support Foundation of Rio de Janeiro State (FAPERJ, APQ1- E-26/111.214/2014) for financial resource provided.

\section{References}

BFG. 2015. Growing knowledge: an overview of seed plant diversity in Brazil. Rodriguésia 66: 1085-1113.
Cervi AC. 1997. Passifloraceae do Brasil. Estudo do gênero Passiflora L. subgênero Passiflora. Fontqueria 45: 1-92.

Escobar LK. 1994. Two new species and a kew to the Passiflora subgenus Astrophea. American Society of Plant Taxonomies. Systematic Botany 19: 203-210.

Feuillet C, MacDougal J. 2003. A new infrageneric classification of Passiflora L. (Passifloraceae). Passiflora: The journal \& Newsletter of Passiflora Society International 13: 34-38.

Haridasan VK, Mukherjee PK. 1988. Seed surface features of some members of the Indian Campanulaceae. Phytomorphology 37: 277-285.

Johri BM. 1984. Embryology of Angiosperms. Berlin, Springer Verlag,.

Killip EP. 1938. The American species of Passifloraceae. Publication Field Museum of Natural History, Botanical Series 19: 1-613.

Mccune B, Mefford MJ. 2006. PC-ORD, version 5.0, Multivariate analysis of ecological data. Glaneden Beach, MjM Solfware Desing.

Mezzonato-Pires AC, Milward-de-Azevedo MA, Mendonça CBF, GonçalvesEsteves V. 2015. Pollen morphology and detailed sexine of Passiflora L. subgenus Astrophea (DC.) Masters (Passifloraceae). Plant Systematic and Evolution 301: 2189-2202.

Milward-de-Azevedo MA, Baumgratz JFA, Gonçalves-Esteves V. 2012. A taxonomic revision of Passiflora subgenus Decaloba (Passifloraceae) in Brazil. Phytotaxa 53: 1-68.

Peréz-Cortéz S, Tillett S, Escala M. 2002. Estudio morfológico de la semilla de 51 especies del género Passiflora L. Acta Botanica Venezuelica 25: 67-96.

Peréz-Cortéz S, Escala M, Tillett S. 2005. Anatomía de la cubierta seminal en ocho especies del gênero Passiflora L., subgénero Passiflora. Acta Botanica Venezuelica 28: 337-348.

Peréz-Cortéz S, Escala M, Tillett S. 2009. Morfoanatomia de la cubierta seminal en siete especies de Passiflora L., subgénero Passiflora (Passifloraceae). Hoehnea 36: 131-137.

Thiers B. [continuously updated]. Index Herbariorum: a global directory of public herbaria and associated staff. New York Botanical Garden's Virtual Herbarium. http://sweetgum.nybg.org/ih/ 15 Feb.16.

Ulmer T, MacDougal JM. 2004. Passiflora: Passionflowers of the world. Cambridge, Timber Press. 